\title{
FenOMENOlogia E PSicopatologia EM SARTRE: "IRREAL NORMAL" E "IRREAL PATOLÓGICO"
}

\author{
Gustavo Fujiwara ${ }^{1}$
}

\begin{abstract}
Resumo: Este artigo pretende investigar a maneira pela qual o filósofo francês Jean-Paul Sartre enquadra, em sua psicologia fenomenológica da imaginaçáo, a problemática acerca do irreal normal e do irreal patológico. Estruturando psicofenomenologicamente a atividade da consciência imaginante, será possível ver que a imagem (consciência imaginante) difere radicalmente da percepção (consciência perceptiva), mas ambas permanecem, contudo, consciência intencional. Nessa toada, cabe a indagação: se toda consciência imaginante é consciência intencional (o que significa, igualmente, que ela é consciência de si mesma), como enquadrar as experiências alucinatórias?
\end{abstract}

Palavras-Chave: Fenomenologia. Psicopatologia. Imaginação. Consciência.

\section{Primeiras observaÇóes aCerCa da natureza da consciênCia imaginante E DA IMAGEM MENTAL: SUAS QUATRO CARACTERÍSTICAS FENOMENOLÓGICAS}

L'imaginaire (1940), obra extensa e densa, tem como objetivo principal descrever aquilo que Sartre indica como a função "irrealizante" da consciência imaginante e seu correlativo noemático, o imaginário. Os ares nos quais Sartre teoriza a imagem são ainda aqueles de uma psicologia definida como "ciência positiva dos fatos psíquicos e de suas leis", descartando "todo ponto de vista imediatamente prático ou estético, toda preocupaçáo ontológica ou normativa." (CUVILLIER apud ELKAÏM-SARTRE, 2010, p. I). Urge ao filósofo, em uma clara atitude de superação dessa ciência que até então figurava como paradigma, uma concepção outra das atividades do psíquico; a pergunta

${ }^{1}$ Doutor em Filosofia pela Universidade Federal de São Paulo (UNIFESP), São Paulo, SP - Brasil.

iD https://orcid.org/0000-0002-3971-9632 E-mail: fujiwaragustavo@gmail.com

Durante o doutoramento, fez estágio de pesquisa na Université Paris VIII. Atualmente, é pósdoutorando em Filosofia, com bolsa Fapesp, no Departamento de Filosofia da Universidade Federal de São Carlos (UFSCar).

http://dx.doi.org/10.1590/0101-3173.2019.v42n1.09.p179 
essencial, portanto, é a seguinte: o que deve ser uma consciência, para que ela possa imaginar? Ou, à guisa de Sartre, "quais são as características que podem ser conferidas à consciência pelo fato de que ela é uma consciência que pode imaginar?" (SARTRE, 2010, p. 343).

O que se seguirá aqui, no que diz respeito ao estatuto da consciência imaginante, ressoará ainda na ambição primeira do autor de construir uma filosofia nova e concreta, a qual, todavia, não significa um primado à matéria e ainda menos à matéria que a ciência positiva estuda. "Ir às coisas mesmas" significa debruçar-se na consciência intencional (toda consciência é consciência de...) e averiguar suas possíveis variaçôes eidéticas; significa, assim, detalhar, através dos mecanismos fenomenológicos, a essência da atividade da consciência:

O concreto o mais indubitável, é para ele (Sartre) o cogito de Descartes. "Penso, logo sou", é a afirmação de que uma consciência reflexiva é possível e que ela é um trampolim sólido para a investigação de outras verdades: para Descartes, se eu posso me enganar sobre a existência do mundo na medida em que eu náo demostrei que há um Deus que garante sua existência, eu posso, ao menos, estar certo de que eu sou, pois penso; do mesmo modo para Sartre "o homem que, em um ato de reflexão, adquire consciência de ter uma imagem não saberia se enganar. (ELKAÏM-SARTRE, 2010, p. V).

Desse pressuposto que permeia a letra sartriana, uma nova orientação se oferecerá a toda psicologia, ou seja, deveremos diferenciar os modos de intencionalidade segundo as situaçóes nas quais a consciência se encontra, pois a consciência é ato e não coisa inerte do mundo. Observaremos, nessa toada, que a concepção de imagem mental não é uma percepção enfraquecida, uma sensação renascente, mas, bem ao contrário, é uma variação eidética da consciência que difere radicalmente da percepção (consciência perceptiva). Todavia, como poderemos detalhar e descrever a atividade da consciência imaginante, ou seja, como poderemos fixar, fenomenologicamente (eideticamente), suas leis? É entáo ao método proposto por Sartre que devemos nos debruçar, neste momento, caso queiramos esgotar a amplitude de uma "fenomenologia da imagem".

2 Tal assertiva é ainda mais clara, quando lembramos que Sartre, para escrever sobre o imaginário, fez uso regrado da mescalina. Desse fato, gostaríamos apenas de frisar que, embora o filósofo esteja convencido de que as localizaçôes cerebrais (ou seja, o fisiológico) possam determinar as condiçôes necessárias para que as funçóes psíquicas existam, "elas jamais darão conta do fato de que eu sou uma consciência que percebe, se lembra, imagina, se projeta no futuro.” (ELKAÏM-SARTRE, 2010, p. III). 
O método ${ }^{3}$ para a análise e fixação da essência da consciência imaginante é, como indica Sartre, o ato de refletir. A imagem somente será descrita por um ato de segundo grau, "pelo qual o olhar se desvia do objeto para dirigir-se sobre a maneira como esse objeto é dado. É o ato reflexivo que permite o julgamento 'eu tenho uma imagem'." (SARTRE, 2010, p. 15). Tal reflexão não é outra senão a reflexão eidética, agora no plano da psicologia. Como já havíamos eludido, algumas linhas acima, Sartre toma para si o que se sabe desde a filosofia cartesiana: "Uma consciência reflexiva nos entrega dados absolutamente certos; o homem que, em um ato de reflexão, toma consciência de 'ter uma imagem' não poderia se enganar." (SARTRE, 2010, p. 15). De acordo com o filósofo, a consciência imaginante se distingue das outras formas de consciência, pois ela possui, no momento de sua aparição à reflexáo, certas características que a informam como tal, possibilitando um julgamento do tipo "tenho consciência de uma imagem". Se assim é, o ato de refletir tem um conteúdo imediatamente certo, que, a partir da obra em comento, chamaremos de essência da imagem; tal essência, a mesma para todo e qualquer homem, deve ser explicitada, fixada e descrita pelo psicólogo. Destarte, faz-se imperativo, antes que possamos adentrar propriamente nas sendas da teoria sartriana da imagem, convir quanto a isso: desde L'imagination (1936), o filósofo frisa que a metafísica ingênua das teorias clássicas da imagem, tanto do lado da psicologia como do lado da filosofia, operavam um embaraçoso equívoco, ao sustentarem que a imagem estava ipsis litteris na consciência, e que o objeto, por seu turno, estava na imagem. Portanto, "fazíamos da consciência um lugar povoado de pequenos simulacros, e esses simulacros eram as imagens." (SARTRE, 2010, p. 17). O que Sartre nomeia como metafísica ingênua da imagem, nos quadros de L'imaginaire, se designará como ilusão da imanência, ou seja, o hábito que possuímos de pensar no espaço e em termos de espaço. ${ }^{4}$ A teoria da intencionalidade, todavia, já nos informara acerca da impossibilidade de introduzir esses "retratos materiais" na consciência (estrutura sintética), sem destruí-la por completo.

\footnotetext{
3 "O método é simples: produzir em nós imagens, refletir sobre essas imagens, descrevê-las, isto é, tentar determinar e classificar seus traços distintivos.” (SARTRE, 2010, p. 16).

4 "A maior parte dos psicólogos e dos filósofos adotou esse ponto de vista. É também aquele do senso comum. Quando digo: 'tenho uma imagem' de Pierre, eles pensam que eu tenho no momento presente certo retrato de Pierre na consciência. O objeto de minha consciência atual seria precisamente esse retrato, e Pierre, o homem de carne e osso, somente seria atingindo muito indiretamente, de uma maneira 'extrínseca', pelo simples fato de que é ele que esse retrato representa." (SARTRE, 2010, p. 19).
} 
Por não aderirmos à ilusão da imanência que nos conduz a constituir o mundo do espírito com os objetos do mundo exterior, diremos que a consciência pode relacionar-se com o X qualquer de dois modos diferentes (perceber ou imaginar). Na percepção, uma cadeira, por exemplo, é "reencontrada" pela consciência, e já no ato de imaginar, não (isso, como veremos, é o modo desinencial da imagem, ou seja, o de aparecer como ausência, nada, fenômeno de quase-observação): não se trata aqui, em nenhum dos dois casos, de um simulacro da cadeira, de uma relação extrínseca com a cadeira existente. De fato, o que existe são dois tipos distintos de consciência que se relacionam, cada qual à sua maneira, com o objeto, sem, no entanto, afirmar que ele está realmente na consciência. $\mathrm{O}$ mecanismo intencional da consciência suprime, de uma vez por todas, os imbróglios das teorias clássicas que não cansavam de afirmar o objeto como imagem exteriorizada e a imagem como objeto interiorizado.

Destarte, no caso que nos interessa aqui (a consciência imaginante), o objeto em imagem designa certa forma que a consciência possui de visá-lo, a imagem é tão somente uma relaçấo: "A consciência imaginante que tenho de Pierre não é a consciência da imagem de Pierre." O filósofo frisa, com isso, a diferença existente entre a matéria da imagem material (fotos, caricaturas, quadros) e a matéria da imagem mental. Além disso, deve-se notar que é o próprio Pierre que é visado pela consciência imaginante: "Minha atenção não é dirigida para uma imagem, mas para um objeto." (SARTRE, 2010, p. 22). Levando em consideração o que acabamos de expor, somos conduzidos a afirmar que a imagem é uma consciência completa que intenciona certos objetos; a imagem não é uma coisa, porém, uma relação: ela é a consciência imaginante de qualquer coisa, e esta é a sua primeira característica. A segunda, a terceira e a quarta característica da imagem dizem respeito, respectivamente, ao fenômeno de quase-observação, ao modo pelo qual a consciência imaginante posiciona seu objeto e à espontaneidade. Debrucemo-nos, neste momento, no fenômeno de quase-observação: Sartre ressalta que um X qualquer pode ser apreendido de três formas diferentes, quais sejam: através da percep̧̧ão, da concepção ou da imaginação. ${ }^{5}$ Observou-se até agora que a imagem não é um elemento presente na consciência, mas uma consciência que intenciona objetos que diferem dos objetos da percepçáo; na consciência perceptiva, eu observo os objetos por perfis (Abschattungen), eles estão diante de mim com sua opacidade característica, nunca são dados por inteiro, "o próprio da percepção é

\footnotetext{
5 "Perceber, conceber, imaginar, tais são, com efeito, os três tipos de consciências pelas quais um mesmo objeto pode nos ser dado." (SARTRE, 2010, p. 22-23).
} 
que o objeto só aparece a ela em uma série de perfis, de projeçôes." (SARTRE, 2010, p. 23). Na percepção, os objetos jamais podem aparecer à consciência, sem que mantenham uma relação marcada pela infinidade perceptiva.

$\mathrm{Na}$ concepção (segunda maneira de visar um objeto), concebemos de uma só vez todos os lados do objeto (seja, por exemplo, um cubo); em um único ato de consciência, somos capazes de pensar suas essências concretas, por isso, esse segundo modo é um saber consciente de si, pois apreende o objeto por inteiro, de uma só vez: não há aprendizado algum; "um, o saber consciente de si mesmo, que se coloca de uma vez no centro do objeto, o outro, unidade sintética de uma multiplicidade de aparências, que faz lentamente seu aprendizado." (SARTRE, 2010, p. 24). É esta, por sua vez, a diferença mais nítida entre pensamento e percepçáo. Entretanto, como pensaremos a imagem, essa terceira via que possui a consciência de colocar seu objeto? Em princípio, a consciência imaginante parece estar "do lado" da consciência perceptiva, na medida em que o objeto, em ambas, nos pode ser dado através de perfis ou projeções. Todavia, o cubo em imagem se dá imediatamente pelo o que ele é, pois não precisamos, tal como na percepção, "dar a volta" nele. Dessa maneira, quando afirmo que possuo a imagem de um cubo, emito um julgamento de evidência, há um saber imediato que envolve o cubo em imagem. A imagem é um ato sintético que une a elementos mais representativos um saber concreto, "ela é exatamente organizada como os objetos que se apreendem, mas, de fato, ela se dá inteiramente como aquilo que ela é, desde sua aparição." (SARTRE, 2010, p. 25). É importante sublinhar que esse cubo em imagem, por ser apreendido inteiramente desde o momento em que ele é concebido pela consciência imaginante, não nos ensina nada; assim, no final da operação, nenhum elemento novo foi apreendido: disso, a indicação de que há na imagem uma pobreza essencial, um número finito de determinaçôes.

No cubo em imagem, vejamos, jamais poderíamos exceder o saber que se tem dele de antemão, porque nós não podemos aprender nada de uma imagem que já não sabíamos antes: a imagem dá, de uma só vez, o que ela possui. N'outras palavras, encontra-se, desde sempre no ato que me deu o objeto em imagem, o conhecimento do que ele é. Ao imaginar, por exemplo, um pedaço de grama, sei imediatamente que essa grama pertence a tal jardim, localizado em tal cidade específica; não há espera, não há aprendizado. Esse modo que possuímos de nos relacionar com o objeto em imagem é o que chamaremos de fenômeno de quase-observação, pois a imagem é também objeto de observação, na medida em que seu conteúdo guarda resquícios da opacidade sensível. 
Essa observação imaginante, todavia, nada informa de novo. Destarte, o fenômeno de quase-observaçáo indica necessariamente que o objeto como imagem é tão somente a consciência que se possui dele.

Entrementes, a consciência imaginante se encontra entre o conceito e a percepção ${ }^{6}$; assim, o objeto, em imagem, é contemporâneo da consciência que tenho dele (semelhante à percepção), mas, como destacamos, o objeto é o correlativo de tudo o que constitui minha consciência (semelhante à concepção). $\mathrm{O}$ objeto correlativo desse ato se constitui como objeto concreto e também como objeto de saber; daí que resulte dessa paradoxal consequência o fato de que o objeto imaginado seja apresentado ao mesmo tempo de fora (concepção) e de dentro (percepção). Apresentado ao mesmo tempo de fora, pois nós o observamos, e de dentro, posto ser nele que nós percebemos o que ele é.

Resta-nos, ainda neste primeiro contato com a teoria sartriana da imagem, precisar sua terceira característica. Se, na percepção, a consciência coloca seu X qualquer como existente, como pensaremos essa operação, na consciência imaginante? Tal como na percepção, há na imagem um ato posicional que pode, de acordo com o filósofo, proceder de quatro formas distintas: a consciência imaginante pode colocar o objeto como inexistente, ausente, existente em outra parte ou neutralizar-se, isto é, não colocar o objeto como existente. "Dois desses atos são negaçóes: o quarto corresponde a uma suspensão ou neutralização da tese. O terceiro, que é positivo, supóe uma negação implícita da existência natural e presente do objeto." (SARTRE, 2010, p. 32).

Devemos distinguir os diferentes casos que envolvem o ato posicional da consciência imaginante: em primeiro lugar, o irreal, ou seja, o que eu imagino pode não existir (imagino um centauro ou uma quimera); em segundo lugar, posso imaginar um objeto ausente (imagino que estou na biblioteca). A partir disso, quando assevero que possuo uma imagem da biblioteca na qual estudo todas as manhãs, isso equivale a dizer que não a vejo agora e que náo estou sentado em uma de suas cadeiras, escrevendo este texto. Em outras palavras, viso a biblioteca como ausente; a imagem dá seu objeto como um nada de ser. Quando, por exemplo, produzo uma consciência imaginante de Pierre, o que faço, de fato, é produzir uma síntese intencional que irá reunir uma série de momentos passados, para que eu possa afirmar uma identidade, através das diversas apariçôes do amigo ausente: Pierre-em-imagem é a sinonímia de Pier-

\footnotetext{
6 "A imagem, intermediária entre o conceito e a percepçáo, fornece-nos o objeto em seu aspecto sensível, mas de uma maneira que, por princípio, a impede de ser perceptível. É que ela o visa, na maior parte do tempo, em toda a sua inteireza." (SARTRE, 2010, p. 181).
} 
re intuitivo-ausente; sua imagem é sempre uma certa maneira de não tocá-lo, de não vê-lo a tal distância de mim. Enfim, a crença na imagem coloca a intuição, e não Pierre. O terceiro caso, por sua vez, diz respeito ao irreal que existe alhures (Pierre está em Berlim), e, finalmente, o quarto e último caso, no qual observamos que "a existência do que é imaginado não é nem afirmada e nem negada, mas como já dizia Husserl, colocada entre parênteses ou neutralizada." (CABESTAN, 1999, p. 9).

Diante de tais asserçóes, afirmaremos que a imagem envolve um certo nada, graças a esse modo posicional específico que a consciência imaginante desvela de conceber seus objetos. Assim, a consciência imaginante será, nos quadros da obra em tela, a estrutura nadificadora da consciência. A imagem é, finalmente, uma certa maneira de a consciência imaginante apreender o $\mathrm{X}$ qualquer ausente, "a consciência de uma imagem é consciência imediata do nada que habita a imagem." (CABESTAN, 1999, p. 9). O nada indica diretamente a característica irreal das imagens, ele distingue a consciência imaginante da consciência perceptiva, por isso, embora façamos um enorme esforço para produzir em nós a crença de que a imagem exista realmente, nós permanecemos incapazes de "destruir a consciência imediata de seu nada” (SARTRE, 2010, p. 35), de sua irrealidade, de sua ausência no campo fenomenal. N'outras palavras, o nada (estrutura) da imagem é responsável por fomentar em nós uma conduta de descrença ante as imagens. ${ }^{7}$ Por fim, a quarta e última especificidade dessa consciência toca diretamente naquilo que Sartre denomina espontaneidade, mas, dessa vez, a despeito da consciência imaginante, a qual, diferentemente da consciência perceptiva, não depende da presença real do objeto, pois ela espontaneamente produz e conserva seu objeto como imagem, devendo assumir, portanto, a liberdade que a atravessa por inteiro: "Apenas uma consciência livre é capaz de evadir-se da realidade, de negá-la e de visar um irreal.” (CABESTAN; TOMÈS, 2001, p. 31). A consciência imaginante

é espontânea e criadora; sustenta, mantém através de uma criação contínua as qualidades sensíveis de seu objeto. $\mathrm{Na}$ percepção, o elemento propriamente representativo corresponde a uma passividade

\footnotetext{
7 Veremos que é somente em determinadas circunstâncias muito precisas, aquelas da patologia da imaginação, que a crença na realidade das imagens é fortificada. Portanto, há uma conduta da consciência que, imediatamente, apreende o nada da imagem, logo, sua ausência ou sua irrealidade, e há, por outro lado, uma conduta alucinante perante a imagem. Se é próprio da imagem dar seu objeto como nada (seu modo desinencial), ainda que ela seja extremamente forte, tocante, "viva”, é lícito perguntar então quais são os "motivos" que nos fazem reagir a essa imagem, como se ela estivesse realmente presente à consciência, tal como um objeto da percepção.
} 
da consciência. $\mathrm{Na}$ imagem, esse elemento, naquilo que ele tem de primeiro e de incomunicável, é o produto de uma atividade consciente, é atravessado de ponta a ponta por uma corrente de vontade criadora. (SARTRE, 2010, p. 37).

Para Sartre, a oposição entre a espontaneidade imaginativa e a passividade perceptiva será uma das chaves fundamentais para o amplo entendimento da eidética da intenção imaginante. Porém, faltam-nos ainda elementos essenciais capazes de distinguir a imagem mental da percepção: sabemos apenas que perceber o $\mathrm{X}$ qualquer ou ter uma imagem dele náo significa, de modo algum, constituir uma mesma matéria, seja em aparência real, seja em aparência imaginária, "decidindo arbitrariamente por uma ou por outra interpretação." (THOMÈS, 2002, p. 254). Tecidos esses breves comentários, vejamos como Sartre distingue o "irreal normal" do "irreal patológico".

\section{2 “IRREAL NORMAL" E "IRREAL PATOLÓGico"}

Neste momento de nossas investigaçóes, procuraremos restituir o tratamento dado por Sartre às chamadas "patologias da imaginação": no que concerne à chamada psicopatologia, teria a fenomenologia sartriana algo a acrescentar-lhe ou reformular? A psicologia fenomenológica pode dar conta do imaginário patológico? Mais: o que Sartre entende como patológico? Podemos falar em normal versus patológico, ou seja, em uma vida psíquica normal, em detrimento a uma vida psíquica patológica? Cabe aqui, portanto, a mesma pergunta eidética: o que deve ser uma consciência, para que ela possa alucinar? Ou melhor, que tipo de desarranjo eidético é operado na consciência, a fim de que ela "substitua" o real pelo imaginário? Se é verdade que imagem e percepção não se confundem, se é vão o esforço para destruir a consciência imediata que temos do nada que galvaniza a imagem, como, todavia, muitos alucinados tomam uma imagem por percepção? imagem é uma consciência que possui, portanto, consciência de si própria enquanto consciência imaginante criadora, como ela pode crer perceber como real o irreal que ela imagina?” (CABESTAN, 1999, p. 28). Além disso, como a consciência pode sentir-se "passiva" diante das imagens que ela mesma cria e

8 "Se é verdade que o alucinado 'toma uma imagem por uma percepçâa', o que significam essas palavras 'tomar por uma percepção'? Será que é preciso entender, como certos psicólogos, que o alucinado confere exterioridade à sua imagem, 'projeta' sua imagem no mundo das percepçóes?” (SARTRE, 2010, p. 286). 
mantém, a partir de sua intencionalidade? Valeria também para os casos patológicos da imaginação a mesma assertiva cartesiana, segundo a qual a reflexão, uma vez operada, nos entregaria dados indubitáveis, de modo a fazer-nos distinguir entre uma consciência de imagem e uma consciência perceptiva? Esse arrazoado de questôes já nos faz pressentir todas as dificuldades e obstáculos conceituais que a fenomenologia sartriana enfrentará, caso queira lançar um olhar outro para os estudos da assim chamada psicopatologia. ${ }^{9}$

Em primeiro lugar, é indelével para Sartre que o esquizofrênico sabe que os objetos que os cerca são, na verdade, irreais; vide, por exemplo, os apontamentos de Borel e Robin (dois psiquiatras do século XX que Sartre utiliza nessa argumentação): a senhora Marie B, depois de uma crise na qual afirmava ser a rainha da Espanha, confessa que, no fundo, sabia que isso não poderia ser verdadeiro. Ela chega mesmo a comparar sua alucinação com as fantasias que as meninas criam, quando brincam com suas bonecas, como se elas fossem seres vivos reais. Até aqui, tudo parece caminhar na mesma direção da teoria sartriana: o modo desinencial de aparição da imagem é, justamente, o de aparecer como imagem, sem jamais confundir-se com uma percepçáo. O filósofo adota como ponto de partida o fato de que todos os indivíduos reconhecem suas imagens enquanto tais; a imagem é um termo vago que significa de uma só vez a consciência e seu correlato transcendente, ela é consciência consciente (tética ou não) da imagem como tal. Nos quadros teóricos de L'imaginaire, portanto, quando o psicólogo destaca que o alucinado "toma uma imagem por uma percepção", ou seja, quando ele confere exterioridade à imagem, projeta-a no mundo real da percepção, tal indicação de exterioridade estaria incidindo sobre consciência ou em seu correlativo transcendente? Ressalta Sartre:

Certamente não seria à consciência; pois não é possível que a consciência se dê por algo que náo seja a consciência. $\mathrm{O}$ cogito cartesiano conserva seus direitos mesmo entre os psicopatas. Mas o objeto de minha consciência imaginante não poderia ser também exteriorizado, pela razão de que já é assim por natureza. Se eu formo a consciência imaginante de Pierre, Pierre traz consigo seu espaço irreal e se coloca ante a consciência, é exterior a ela. (SARTRE, 2010, p. 286-287).

9 Para Cabestan (2004, p. 181), Lagache, entấo médico do Hospital Sainte-Anne e autor da obra Les hallucinations verbales et la parole (1934), é aqui uma das referências principais de Sartre, no que tange ao estudo da psicopatologia. Além dele, o filósofo também segue algumas orientaçōes teóricas de Pierre Janet - titular da cadeira de psicologia patológica do Collège de France (1902-1933) - apresentadas em L'automotisme psychologique (1889), Les Obsessions et la psychasthénie (1911) e Les Névroses (1909). 
Não sendo exterior nem à consciência imaginante e nem a seu objeto, o qual já é exterior por natureza, o problema parece configurar-se em outros termos. Façamo-nos melhor entender. Em primeiro lugar, o objeto da imagem difere do objeto da percepção; o primeiro possui seu espaço próprio, em detrimento do espaço infinito dos objetos percebidos. Ademais, há uma irrealidade imediatamente apreendida na imagem, que é correlativa de uma intuição imediata de espontaneidade. Assim, ao constituirmos a imagem mental, em duplo movimento, apreendemos a espontaneidade da consciência e a irrealidade do objeto: "A consciência possui uma consciência de si não-tética como uma atividade criadora." (SARTRE, 2010, p. 287). A consciência espontânea aparece, como assinala Sartre, como uma consciência transversal que compóe junto com a consciência do objeto uma só consciência, ou seja, toda consciência é consciente de si (de sua espontaneidade) e do objeto apreendido, de sorte que a consciência só toma consciência de si mesma (teticamente ou não) a partir da apreensão do objeto, seja objeto da percepção, seja objeto em imagem. Doravante, nós nos deparamos aqui com o estatuto da estrutura psíquica, estrutura independente do estado de doença (patológico) ou saúde (normal) mental do indivíduo. No entanto, qual é o sentido dessa afirmação, o que ela indica? Ora, asseverar que essa estrutura psíquica independe de estados mentais, quer normais, quer patológicos, significa indicar que a consciência, totalidade sintética, opera em regime transcendental. ${ }^{10}$ A consciência é consciência espontânea e consciência do objeto (consciência pré-judicativa, absoluta, autárquica), pois ela é galvanizada por uma lei eidética, a qual, operando no campo transcendental, torna-a autônoma dos estados mentais do sujeito; antes de ser saudável ou doente, a estrutura psíquica é transcendental. Tratando-se de uma necessidade eidética, "a consciência mórbida permanece para Sartre uma consciência, isto é, uma espontaneidade incondicional”, na qual "o princípio da translucidez da consciência se aplica identicamente à consciência quer ela seja normal ou patológica.” (CABESTAN, 2004, p. 183). É imperativo frisar: toda consciência imaginante detém as mesmas estruturas noético-noemáticas da percepção e, como consequência, "pouco importa que a consciência seja 'mórbida' ou não; é uma necessidade de essência que o objeto real seja constituído como irreal." (SARTRE, 2010, p. 291-292). Todavia, a verdadeira questão persiste: como nós abandonamos nossa consciência

\footnotetext{
${ }^{10}$ Esse regime transcendental significa, grosso modo, as operaçôes da consciência irrefletida impessoal. O campo transcendental impessoal designa, desde La transcendance de l'ego (1937), a consciência irrefletida como pura atividade, isto é, como puro movimento de transcendência intencional em direção ao $\mathrm{X}$ qualquer. Além disso, esse campo transcendental impessoal postula a ausência de qualquer estrutura egológica que seria responsável pela constituiçấo do caráter do sujeito.
} 
de espontaneidade, como nos sentimos passivos, diante das imagens que de fato formamos? "É verdade que conferimos realidade, isto é, uma presença de carne, a esses objetos que se dão como ausentes a consciência sâ?" (SARTRE, 2010, p. 287). Enfim, já que a percepção e a consciência imaginante são duas atitudes alternadas, "será possível que façamos a fusão do espaço da imagem como o da percepção no caso da alucinação, como um alucinado que dissesse, por exemplo: 'Nesta cadeira (real) eu vi o diabo (irreal)'?" (SATRE, 2010, p. 287). Sobressai dessa indagação o verdadeiro problema colocado pela psicopatologia: como a espontaneidade da consciência pode deixar de ser consciência dessa espontaneidade? Havendo uma estrutura psíquica independente dos estados mentais, vê-se que o estado doente (patológico) não pode "alterar" o funcionamento transcendental da consciência e cabe, então, perguntar: como, ainda assim, a consciência se sente passiva em face das imagens que ela mesma cria e fomenta, graças à sua espontaneidade? Se espontaneidade é sinônimo de liberdade, ocorreria a perda dessa liberdade constitutiva e a patologia faz emergir o tema da passividade?

Em primeiro lugar, é preciso tomar certo distanciamento em relação às confissóes do doente, porque nada pode provar que o espaço da imagem coabite o espaço da percepção: é falsa, nesse sentido, a afirmação de que o diabo (irreal) tenha sido visto sobre a cadeira (real) que pertence ao espaço da percepção. A alucinação, longe de coexistir junto à percepção, indica um tipo de aniquilação da realidade percebida, e é somente após relatá-las ao psiquiatra que o doente lhes dá um lugar no espaço real da percepção. No entanto, faz-se imperativo apontar que há, de fato, um ato alucinatório que aparece bruscamente ao doente, ao passo que suas percepçóes desvanecem; "a alucinação visual ou auditiva é acompanhada de um desmoronamento provisório da percepção. Mas, quando o choque alucinatório passa, o mundo reaparece" (SARTRE, 2010, p. 291); as alucinaçôes, verbais ou imagéticas, não são vistas e nem ouvidas no espaço real da percepção; a localização espacial se faz depois, pois ela é um problema secundário que se desdobra de uma questão mais geral: como compreender o fato de que a alucinação se impóe à consciência? Ora, que tipo de operação ocorre, para que o doente acredite na realidade de uma imagem que, por definição, é dada imediatamente como irreal e ausente? ${ }^{11} \mathrm{Se}$ a patologia é identificada quando da produção de imagens de uma consciência imaginante, o problema, ainda, poderia figurar nos seguintes termos: o que

${ }^{11} \mathrm{O}$ problema poderia ser ainda esboçado da seguinte maneira: como uma ausência aparece como presença? 
ocorre, para que os dados da consciência imaginante operem como dados da consciência perceptiva, ou seja, por qual razão e como a imagem, cujo modo desinencial é o de aparecer como irreal, aparece tal como o X qualquer e real da consciência perspectiva? A psicologia fenomenológica, ao adentrar no terreno sinuoso da psicopatologia, poderia lançar luz sobre esse fato?

Almejando responder a essa questão crucial $^{12}$, L'imaginaire operará uma comparação entre a alucinação e a obsessão. Antes de nos debruçarmos sobre os mecanismos obsessivos, a questão colocada acima revelaria que se trata ali de uma alteração da crença ou, como destaca ainda o filósofo, da tese? A resposta é negativa. Se, mesmo em uma consciência mórbida, a estrutura psíquica continua operando em regime de normalidade fenomenológica ${ }^{13}$, a tese constitutiva da imagem (dar-se como irreal) náo poderia ser alterada, havendo uma necessidade de essência que permeia toda a estrutura da imagem; é seu modo desinencial de aparição, "a produção do objeto irreal coincide com a consciência de sua irrealidade” (SARTRE, 2010, p. 292); não podemos destruir tal irrealidade, sem, ao mesmo tempo, destruir essa consciência espontânea. A irrealidade do objeto em imagem é correlativa da consciência imaginante, isto é, essa irrealidade é o modo desinencial do objeto em imagem. Tăo logo esse fato fenomenológico tenha sido exposto, seremos forçados a admitir que, mesmo na alucinação, a consciência não poderia constituir a imagem mental, sem apreender ao mesmo tempo a sua irrealidade. $\mathrm{O}$ autor, ciente dos obstáculos colocados pela psicopatologia, salienta:

Parece, após esse primeiro exame, que nós terminamos em um impasse e que seja necessário mudar alguma coisa de nossa teoria ou abandonar alguma de nossas exigências. Mas talvez a alucinação não se caracterize por uma alteração da estrutura primária da imagem; talvez ela se dê mais como uma perturbaçáo radical da atitude da consciência em face do irreal. Numa palavra: talvez, trate-se de uma alteração radical de toda consciência, e a mudança de atitude diante do irreal somente apareceria como uma contraparte de um enfraquecimento do sentido do real. (SARTRE, 2010, p. 293).

\footnotetext{
${ }^{12}$ Crucial, na medida em que ela objeta à teoria sartriana da imagem o fato de que a imagem, em sua essência, se dá à consciência imediatamente como ausente, irreal e atravessada por um nada.

${ }^{13}$ Indicamos por normalidade fenomenológica o funcionamento constitutivo da consciência, na qual a espontaneidade é espontaneidade consciente, seja esta consciência de primeiro, seja de segundo grau, isto é, consciência irrefletida ou consciência reflexiva.
} 
As reações à imagem (estrutura secundária) poderiam afetar a consciência até esse ponto, mudar totalmente sua estrutura? Usando uma observação ${ }^{14}$ tecida por Lagache, o filósofo explicita que o acontecimento alucinatório ocorre a partir de uma perturbação positiva "sobre um fundo de apatia perceptiva em que os objetos aparecem como irreais." (SARTRE, 2010, p. 295). Assim, caso a alucinação reencontre o mundo real da percepção, ela só o pode, quando esse mundo real não é de fato percebido, mas sim sonhado e irreal. Doravante, antes de haver uma sobreposição de dois mundos, o doente, alucinando, já estaria completamente submerso no mundo sonhado por ele. Vejamos toda a amplitude dessa ideia, em função de um fenômeno que também se impóe à consciência ${ }^{15}$ : a obsessão. De acordo com Sartre, costumava-se opor uma suposta riqueza inesgotável das imagens alucinatórias à característica estereotipada da obsessão. Todavia, se estamos de acordo com a pobreza essencial do material alucinatório, ver-se-á que a alucinação "se apresenta como a reaparição intermitente de certos objetos (sonoros ou visuais)" (SARTRE, 2010, p. 295); daí que ela se aproxime da obsessão que coloca a aparição intermitente de certas cenas, sejam estas mais ou menos estereotipadas. Sobretudo depois dos trabalhos de Janet, compreendeu-se que a obsessão não teria uma característica subjetiva, ao passo que as imagens da alucinação seriam exteriores. $\mathrm{O}$ psicólogo francês, de acordo com Sartre, teria mostrado que a obsessão não é uma espécie de corpo estranho que viria ocupar a consciência, tal como um cálculo ocupa o rim: ela não é o outro da consciência, mas uma consciência. Doravante, não devemos conceber o estado patológico como uma representação ontológica do mal, um ser da doença em justa oposição ao ser da saúde ${ }^{16}$, logo, como o outro na consciência, o seu avesso. Se, fenomenologicamente falando, o objeto irreal é constituído como tal, não importando que a consciência seja "mórbida" ou não, o patológico, no corpus sartriano, é apreendido a partir do normal no qual ele fomenta uma alteração ${ }^{17}$, pois a imagem

\footnotetext{
14 "Lagache observa que 'em alguns casos nenhum dado psicológico parece distinguir a palavra alienada da palavra normal; o doente sabe desde o começo que não era ele quem falava, como se o tivesse decidido, sem que possa captar os dados concretos que determinam e motivam sua decisáo'." (LAGACHE apud SARTRE, 2010, p. 293).

15 "Se acreditarmos em muitos psicólogos, a alucinação e a obsessấo impôem-se ao espírito." (SARTRE, 2010, p. 296).

${ }^{16}$ Pensamos, em partes, o tema do normal e do patológico ancorados no livro de Georges Canguilhem, Le normal et le pathologique (1943). Sobre a visão médica da doença como representação ontológica do mal, ver a primeira parte dessa obra.

${ }^{17} \mathrm{O}$ patológico é apreendido a partir do normal, assim como o irreal é constituído sob fundo de mundo real.
} 
patológica não poderia escapar da universalidade constitutiva da consciência imaginante. Lê-se:

\begin{abstract}
Sartre, neste ponto, permanece fiel a Husserl, e do mesmo modo que para o fundador da fenomenologia a normalidade "deve, de início, ela mesma se constituir como tal, e ela somente o pode sob o fundo de uma normalidade provável". [...] se uma consciência imaginante patológica possui uma estrutura fundamentalmente idêntica à consciência imaginante normal, isso implica que a obsessão ou a alucinação, enquanto consciências humanas em geral, possuem cada uma, uma unidade imanente e, enquanto consciências de imagens, são consciências (delas) mesmas, por consequência, de suas espontaneidades assim como da irrealidade de seus objetos. (CABESTAN, 2004, p. 184).
\end{abstract}

Ademais, sem esse modo desinencial que imediatamente assinala a irrealidade dos objetos imaginários, a alucinação apareceria tal como a consciência perceptiva. Nesse sentido, o mesmo vale para a obsessão: ela é uma consciência e, portanto, deve possuir as mesmas características de espontaneidade e autonomia, como todas as outras consciências. Nesse esteio, a consciência obsessiva é uma consciência imaginante "sobre a qual lançou-se uma proibição, ou seja, que o psicastênico proibiu a si mesmo de formar." (SARTRE, 2010, p. 296). O doente, temoroso em não mais querer pensar sobre algo, coloca a si mesmo em um movimento vertiginoso que faz renascer esse temor. Quanto mais o doente se esforça para não pensar naquilo que o assombra, mais esse pensamento, via espontaneidade, torna-se pensamento obsessivo. Enclausurada por si mesma em um círculo vicioso, a consciência, ao pretender expulsar esse pensamento, acaba nutrindo-o com mais força: "Todos os esforços que ela faz para expulsar o pensamento obsessivo são precisamente os meios mais eficazes para fazê-lo renascer." (SARTRE, 2010, p. 297). O movimento vertiginoso, por seu turno, assinala essa experiência paradoxal de uma consciência atraída justamente por aquilo que a aterroriza "e que, fascinada, sucumbe como vencida por uma força mágica." (CABESTAN, 2004, p. 184); fomentando seu próprio aprisionamento, a consciência passa a ser refém de si mesma. Daí o paradoxo que atravessa uma consciência obsessiva, qual seja, pensar aquilo que náo se deseja pensar e, nesse movimento, colocar-se nesse círculo vicioso cuja base é a vertigem.

Não obstante, Sartre, fiel ao princípio fenomenológico de que toda consciência é consciência espontânea do objeto e de si mesma (teticamente ou não), atenta para o fato de que o doente está perfeitamente consciente do círculo 
vicioso que cria: ele é, ao mesmo tempo, vítima e carrasco; o filósofo assevera sua tese da espontaneidade: "Nem por um segundo o psicastênico perde a consciência de sua espontaneidade, nem muito menos a impressão formal de personalidade; nem por um instante ele toma os objetos em imagem por objetos reais." (SARTRE, 2010, p. 297). Em face dessa afirmação contundente, notamos que, mesmo em consciências mórbidas, a estrutura noético-noemática da consciência continua operando em regime fenomenológico e, por conseguinte, continua apreendendo o objeto em imagem imediatamente galvanizado por sua irrealidade. Ainda assim, esse princípio não explica o fato de o doente tomar suas imagens irreais - ausentes - como imagens presentemente reais.

Talvez possamos encontrar a chave da vertigem obsessiva caso voltemos ao ensaio La transcendance de l'ego (1937) e à maneira como é enquadrada ali a chamada reflexão impura: quando, por um fato contingente qualquer, a consciência apreende a si mesma como infinitamente livre, ela, como recusa dessa liberdade eidética, confere falsamente ao ego e a seu cortejo de equívocos (estados, açôes e, facultativamente, qualidades) uma pseudoespontaneidade: nesse registro fetichista, a consciência é dada como emanando dos estados, e os estados como produzidos pelo ego. A reflexão impura, região antifenomenológica par excellence, advém para mascarar a liberdade da consciência (a espontaneidade): a função do ego, como o próprio Sartre observou, no opúsculo dos anos 1937, parece ser mais prática do que teórica. Tal função, por seu turno, poderia ser constatada com base em relatos de uma jovem psicastênica que se lançava à janela para flertar com os transeuntes, sempre que se encontrava sozinha. Na origem dessa atitude, encontrávamos uma consciência que apreendia sua liberdade: "nada em sua educação, em seu passado, nem em seu caráter pode servir de explicação a semelhante temor." (SARTRE, 2003, p. 128). Portanto, nos quadros teóricos do ensaio, essa vertigem encontrava sua origem quando, repentinamente, a consciência aparecia a si mesma como transbordando infinitamente suas possibilidades. Sem os recursos práticos oriundos do ego da reflexão impura, a jovem se achava inteiramente "nua" diante da monstruosa liberdade de sua consciência, diante da monstruosa liberdade de sua consciência (ou seja, o fato fenomenológico de que toda consciência é consciência de...). Solidificando o que fora realçado em La transcendance de l'ego, L'imaginaire assinala que, no processo psicastênico, "o sentimento de pertencer ao eu, o que Claparède chama 'a inserção no próprio eu”" (SARTRE, 2010, p. 297), desaparece. Quando sustentamos que a obsessão se impóe, esse fato indica que "eu não chego a reportar este tipo de consciência a meu ego: parece que ela não vem de mim” (CABESTAN, 2004, p. 186); o eu já não é 
uma síntese harmoniosa de empreendimentos sobre o mundo. ${ }^{18}$ Encontrando em seu caminho certas interdiçóes, parece que o psicastênico não deseja mais reconhecer como sua essa consciência espontânea.

Afirmar que a consciência mórbida se impóe ao doente significa declarar "que o Eu da reflexão impura, longe de poder situar-se na origem da obsessão, aparece, ao contrário, passivo e estranho a essas espontaneidades." (CABESTAN, 2004, p. 187). Antes de aparecer "passivo e estranho", frisamos que o ego, na verdade, não chega nem a advir a essas espontaneidades mórbidas e que, justamente por isso, só resta ao doente refugiar-se no irreal ou, no caso da obsessão, encontrar-se passivo diante da liberdade da consciência. Destituído o sentimento do eu, o doente se encontraria totalmente nu, frente à vertiginosa liberdade da consciência que, por seu turno, desencadearia as reaçóes de fuga do real como único meio para solapar, mesmo que por um instante, essa liberdade monstruosa. Para fortificar o que asseveramos, lembremos o ensaio dos anos 1937: "É graças ao ego, com efeito, que uma distinção poderá se efetuar entre o possível e o real, entre a aparência e o ser, entre o querido e o sofrido." (SARTRE, 2003, p. 129). Ademais,

pode acontecer que a consciência se produza repentinamente, ela mesma, sobre o plano reflexivo puro. Talvez não sem ego, mas como que escapando do ego por todos os lados, como que o dominando e o sustentando fora dela por uma criação continuada. Sobre este plano não há mais distinçóes entre o possível e o real já que a aparência é o absoluto. Não há mais barreiras, mais limites, mais nada que dissimule a consciência a ela mesma. Então, a consciência, apercebendo-se daquilo que se poderia chamar a fatalidade da espontaneidade, angustia-se completamente: é esta angústia absoluta e sem remédios, este medo de si, que nos parece constitutivo da consciência pura e é ela que dá a chave da perturbaçáo psicastênica. (SARTRE, 2003, p. 129, grifo nosso).

Enfim, a partir das constataçóes do ensaio sobre o ego transcendente, somadas aqui à psicologia fenomenológica da imaginação, enfatizaremos que a perturbação psíquica, a patologia tal como Sartre a compreende, assinala uma consciência incapaz de recorrer ao ego psíquico, quando de sua descoberta de si mesma como espontaneidade/intencionalidade livre. O psicastênico, tomando consciência da miríade de suas possibilidades, vê-se vertiginosamente livre diante de seus atos. Com base nessa observação, dir-se-á, talvez, que a

18 "Há espasmos do eu, uma espontaneidade que se libera; algo produzido como uma resistência do eu a si próprio." (SARTRE, 2004, p. 298). 
consciência mórbida é o resultado de uma consciência que se sabe completamente atravessada pela liberdade, melhor, a morbidez advém à consciência quando esta, por um fato contingente qualquer, se compreende como a única doadora de sentido do mundo. Náo obstante, não podemos afirmar que toda consciência, ao descobrir-se livre, se tornaria mórbida e desencadearia um processo patológico. Longe de universalizarmos aqui a experiência da liberdade como irromper da patologia, sublinharemos que algumas consciências experimentam sua espontaneidade sem, no entanto, iniciar um processo mórbido. Por morbidez (logo, por patológico), no horizonte do que fora exposto por nós, designaremos uma alteração qualitativa total da atitude da consciência face ao irreal. Essa alteração provoca um aumento qualitativo na crença da realidade da imagem ao mesmo tempo que se inicia uma diminuição, também qualitativa, do sentido do real. Antes de figurarem como diminuição e aumento no sentido quantitativo, o aumento da crença no irreal e o enfraquecimento do real são fenômenos de valor qualitativo, pois, como frisamos anteriormente, ambos coincidem com um brusco aniquilamento da realidade percebida, ambos emergem do mundo tornado irreal, logo, de uma alteração qualitativa da consciência. Nessa alteração está contida a experiência angustiante e impactante do desvelamento da liberdade da consciência, que chega a anular até mesmo as funções práticas do ego. De maneira geral, são condições sine qua non da consciência mórbida: 1) a passividade egoica, 2) o mundo sonhado em contraposiçáo ao mundo percebido, 3) a ausência, 4) a crença e 5) a liberdade constitutiva da consciência (a espontaneidade). ${ }^{19}$

Chegamos, finalmente, à origem da obsessão, a seu ponto nevrálgico: a indômita espontaneidade que abarca a consciência como livre movimento de transcendência em direçáo ao X qualquer. A vertigem obsessiva é o resultado, digamos assim, do embate entre o indivíduo e a espontaneidade que escapa a qualquer síntese pessoal (por exemplo, o ego psíquico), daí que a obsessão e a alucinação se imponham ao espírito. Contudo, ainda não está claro como o doente pode tomar o irreal como real. Se almejamos responder a esse impasse, voltemo-nos aos casos de alucinação, mais precisamente às psicoses alucinatórias. Tanto quanto a obsessão pode figurar como a aparição descontínua de ce-

\footnotetext{
${ }^{19}$ Assim, "a obsessão é, em primeiro lugar, uma angústia a respeito da espontaneidade enquanto ela escapa ao eu e a vontade: e ela pode ser descrita como uma 'vertigem da possibilidade' que é, no fundo, a essência própria da vertigem: posso lançar-me sempre no vazio: a consciência se deixa enfeitiçar pela possibilidade que ela poderia ter, pois nada saberia impedi-la de fazer isso ou aquilo [...]. A angústia comum de se escapar sem cessar, se sucede o terror de uma consciência encantada, aterrorizada por sua própria espontaneidade que é ao mesmo tempo a vítima e o carrasco. É, portanto, a consciência que, espontaneamente, engendra, alimente, ou mantém a obsessão." (CABESTAN, 2004, p. 189-190).
} 
nas mais ou menos estereotipadas, a alucinação também deve ser analisada em função da pobreza característica e da espontaneidade da consciência imaginante: "Sem sombra de dúvida essas consciências são também espontâneas. Sem dúvida trata-se também de um estereótipo que tem como causa uma vertigem obsessiva." (SARTRE, 2010, p. 298). Destarte, a alucinação, assim como a obsessão, é realizada pelo doente a partir dos mecanismos da vertigem obsessiva à qual aludíamos, alguns parágrafos acima: a alucinação também se impóe ao alucinado que não a reconhece como sua, ou seja, ela se impóe à consciência. Como já notamos, L'imaginaire se mantém fiel à incompatibilidade existente entre percepção e consciência imaginante, portanto, "longe de operar a fusão do espaço da imagem com o espaço da percepção, a alucinação, assim como os delírios confessionais e o sonho, exclui a percepção" (CABESTAN, 2004, p. 194); a alucinação obedece, nessa perspectiva, ao fenômeno de quase-observação. A alucinação não é realmente vista ou ouvida, ela não poderia conter, como na percepção, a riqueza que aos poucos descubro nos objetos perceptivos; ela é, na verdade, uma intenção em direção à imagem "que pode ser anterior à constituição do objeto imaginado, uma passagem do saber intencional à consciência imaginante" (SARTRE, 2010, p. 298): o doente só pode alucinar sobre aquilo que, de antemão, ele conhece; ele nunca é pego de surpresa por sua alucinação, ele não a contempla, antes, ele a realiza. Ele a realiza porque, assim como o obsessivo, ele almeja escapar dela. Localiza-se aqui aquela mesma vertigem que expomos, quando da obsessão, e que leva o doente a pensar justamente aquilo que ele teme pensar. Em outras palavras, a alucinação é engendrada por uma vertigem obsessiva, "mas, no caso do alucinado, uma modificação muito importante surgiu: a desintegração." (SARTRE, 2010, p. 299).

Destrinchemos o sentido da última constatação. Em primeiro lugar, a unidade da consciência, logo, a unidade sintética de momentos psíquicos, permanece intacta no doente, pois ela é a condição intrínseca, tanto para o funcionamento normal do pensamento como para as perturbaçóes mentais. Portanto, quando tratamos de uma modificação que leva à desintegração, referimo-nos ao desarranjo da síntese pessoal que afeta o sentimento de pertencer ao eu: há uma incapacidade, uma passividade na estrutura egoica, que a impossibilita de realizar sua funçáo prática de mascaramento do campo transcendental impessoal. Todavia, no caso específico da alucinação, esse fenômeno se acentua, ao ponto de notarmos um desaparecimento das formas superiores de 
integração psíquica. ${ }^{20}$ Ora, esse desaparecimento assinala que não há mais "desenvolvimento harmonioso e contínuo do pensamento, realizado pela síntese pessoal", síntese esta amparada na figura do ego. Tal estrutura, tendo desaparecido, faz com que o curso do pensamento, ainda que vise a um desenvolvimento coerente, seja rompido por "pensamentos laterais", os quais náo se colocam no estado de pensamentos possíveis, na medida em que impulsionam a consciência, via vertigem, a realizá-los imediatamente. Sem essa síntese pessoal que funcionaria como uma, digamos, espécie de filtro, a consciência é impelida a realizar tais pensamentos. No limite, sem a síntese pessoal, a consciência se mostra radicalmente consciência imediata e espontânea de todo e qualquer pensamento: "A condição primeira da alucinação nos parece ser uma espécie de vacilação da consciência pessoal. O doente está só, seus pensamentos se embaraçam de repente, dispersam-se", logo, "à ligação sintética por concentração substitui-se uma ligação difusa e degradada por participação; essa queda de potencial traz para a consciência uma espécie de nivelamento; simultânea e correlativamente, a percepção se obscurece e se confunde: o objeto e o sujeito desaparecem juntos." (SARTRE, 2010, p. 302-303).

Não havendo mais sintese pessoal e pensamento orientado, a espontaneidade imaginante se desenvolve sobre as bordas da consciência: isso a impossibilita de integrar a alucinação como sendo um produto de sua própria espontaneidade, e o sujeito, nesse sentido, encontra-se completamente incapaz de reportar seus estados ou açóes ao ego. Desprovida de unidade temática, a alucinação é, por conseguinte, o resultado de espontaneidades impessoais correlativas de uma consciência impessoal. Ao contrário de uma consciência pessoal provida de unidade temática pela qual toda percepçáo é dada como podendo ser observada e todo pensamento como podendo ser meditado, a consciência impessoal, desestruturada, não pode nem observar e muito menos meditar, pois sua síncope é marcada por uma pura atividade indiferente: tudo o que aparece é, ou, para usar a expressão de Sartre, no ensaio dos anos 1937, "a aparência é o absoluto". Ademais, se a alucinação é um fenômeno engendrado por uma consciência imaginante patológica, devemos lembrar que o mundo real (mundo definido como unidade de relaçóes infinitas entre os objetos), no processo imaginativo mórbido, não pode mais agir sobre a consciência, o que significa, assim, "que o real enquanto tal se obscurece progressivamente e se contrai em um todo indiferenciado.” (BREEUR, 2012, p. 266).

20 "O imaginário repousa, portanto, sobre uma espontaneidade que se libera, implicando por vezes uma liberação de consciências laterais, marginais e correlativas de uma consciência impessoal, que perfuram as formas superiores de integração psíquica, ou seja, o eu.” (BREEUR, 2012, p. 271). 
Ora, se, no processo "irrealizante normal", o mundo é irrealizado a partir da imagem, no processo alucinatório, a irrealização/nadificação do mundo é acentuada, pois, perfuradas as formas superiores de integração psíquica, a consciência, agora totalmente impessoal, está desprovida de unidade temática: ela é atividade indiferenciada. Doravante, sem pessoalidade, a consciência não poderia, por um ato de reflexão, posicionar a irrealidade do mundo, do espaço e do tempo. Contudo, o que isso indica? Bem, em primeiro lugar, uma diferença estrutural entre irreal normal e irreal patológico. No caso do primeiro, pudemos constatar que a imagem mental, em um mesmo movimento, coloca o objeto em imagem e sua consequente irrealidade: possuindo unidade temática, essa consciência imaginante normal é capaz de afirmar a ausência como tal (ela segue o princípio fenomenológico para o qual toda imagem aparece necessariamente como imagem). Na segunda, a apreensão da irrealidade do objeto é incapaz de colocar-se, porque a consciência, sendo impessoal, se ausentou de unidade temática, ou seja, de sujeito. Finalmente, podemos dizer que o irreal normal é a expressão de uma consciência normal, e o irreal patológico, por sua vez, o sintoma da consciência impessoal.

FUJIWARA, G. Phenomenology and psychopathology in Sartre: the "normal unreal" and the "pathological unreal". Trans/form/ação, Marília, v. 42, n. 1, p. 179-200, Jan./Mar., 2019.

ABSTRACT: The aim of the present article is to investigate how the French philosopher Jean-Paul Sartre understood, in his phenomenological psychology of the imagination, the problematic of the "normal unreal" and the "pathological unreal". By psycho-phenomenologically structuring the activity of the imaginative consciousness, we can see that the image (imaginative consciousness) differs radically from perception (perceptive consciousness), but both remain intentional consciousness. In this context, it is necessary to ask the following question: if all imaginative consciousness is intentional consciousness (which also means that it is self-consciousness), how can we frame hallucinatory experiences?

KeYwOrds: Phenomenology. Psychopathology. Imagination. Consciousness.

\section{REFERÊNCIAS}

BREER, R. Le temps irréeal (Sartre). Bulletin d'analyse phénoménologique, Liège, v. VIII, n. 1, p. 261-272, 2012.

CABESTAN, P. L’imaginaire: Sartre. Paris: Ellipses, 1999. 
L'être et la conscience: recherches sur la psychologie et l'ontophénoménologie sartriennes. Paris: OUSIA, 2004. ; THOMÈS, A. Le vocabulaire de Sartre. Paris: Ellipses, 2001.

CANGUILHEM, G. Le normal et le pathologique. Paris: PUF, 2013.

ELKAÏM-SARTRE, A. Introduction. In: SARTRE, J.-P. L'imaginaire. Paris: Gallimard, 2010.

SARTRE, J.-P. La transcendance de l'ego et autres textes phénoménologiques. Texte introduits et annotés par V. de Coorebyter. Paris: J. Vrin, 2003. . L'imaginaire. Paris: Gallimard, 2010. (Folio). . L'imagination. Paris: PUF, 2012. (Quadrige).

THOMĖS, A. Sartre et la critique des fondements de la psychologie: quelques piste sur les apports de Sartre et de Politzer. Bulletin d'analyse phénoménologique, Liège, v. VIII, n. 1, p. 223-244, 2012. 
FUJIWARA, G. 